\title{
Biogas Production from Tannery Liquid Waste
}

\author{
Aisha Elawad Mohamed Elamin, and Gurashi Abdalla Gasmelseed
}

\begin{abstract}
This study investigated the possibility of producing biogas from tannery waste water (liming and deliming liquors) in Al-Amatounj Tannery in Khartoum. The study is based on laboratory analysis and experimental works which have been took place through a pilot scale anaerobic sequencing batch reactor (ASBR), which's designed for the digestion process for biogas production. Experiments verified that the biogas production rates were mainly affected by operating temperature, $\mathrm{pH}$, and substrate concentration. Two experiments were carried out in the range of temperature (35 to 40$){ }^{\circ} \mathrm{C}$. The gas produced was measured by the liquid displacement system. Meanwhile, the highest biogas yields were $72 \%$ ofmethane $\left(\mathrm{CH}_{4}\right)$ and $28 \%$ of carbon dioxide $\left(\mathrm{CO}_{2}\right)$. The production of biogas from $20 \mathrm{~L}$ tannery waste water with $100 \mathrm{~g}$ yeast, $0.0215 \mathrm{~m}^{3}$, and the biogas was generated after three days. The results from this research work are considered as providing useful information and operational parameters and that promotion is more successful with efficient anaerobic codigestion.
\end{abstract}

Index Terms-Effluent; Anaerobic; Methane; Tannery Waste.

\section{INTRODUCTION}

Energy crisis, climate change and increased level of wastes (solid or liquid) are becoming key issues all over the world to assure sustainable development. Furthermore, waste produced either by inhabitants or by industrial companies is considered to be the other most serious environmental problems emitting huge amounts of greenhouse gases and causing water and soil pollution [1].

Tanning industry is considered to be a major source of pollution and tannery wastewater in particular, is a potential environmental concern [2].

In Sudan, modern tanning industries started in 1945. Currently, there are more than 20 tanneries under operation and these tanneries produce wastewater daily which is disposed to the surrounding without proper treatments in addition to tanneries' solid waste. Anaerobic treatment is considered as sustainable method of reducing pollution from tanning industries and produces renewable energy in the form biogas.

\section{MATERIALS AND MethodS}

Abbreviation: ASBR is anaerobic sequencing Batch reactors, $\mathrm{CO}_{2}$ is carbon dioxide, $\mathrm{CH} 4$ is methane gas, $\mathrm{BOD}$

Published on October 30, 2018.

A. E. M. Elamin is with college of Graduate Studies and Scientific Researches. Karary University, Sudan, Omdurman (e-mail: nazirations@yahoo.com, aishaawdme@gmail.com).

G. A. Gasmelseed is with Dept. of chemical Engineering, Faculty of Engineering, University of Science and Technology, Sudan, Omdurman, (email: aishaawdme@gmail.com). is bio chemical oxygen demand, COD5 is chemical oxygen demand consumed in five days, $\mathrm{pH}$ represents Power hydrogen, T.S is total solid, TVS is total volatile solid, Ec is electrical conductivity, $\mathrm{C} / \mathrm{N}$ represents carbon nitrogen ratio, NH3 is ammonia gas.

The study used Beam House Liquors. Brewer's Yeast, Plastic Digester used as a pilot-scale Anaerobic Sequencing Batch reactors (ASBR) as in Fig. 3 with an operational volume of $25 \mathrm{~L}$. The ASBR filled by $10 \mathrm{~L}$ of liming and $10 \mathrm{~L}$ of deliming for test number (1). In test number (2) the ASBR filled by $12 \mathrm{~L}$ of liming and $12 \mathrm{~L}$ of deliming.

Sodium hydroxide is one of the alkaline solutions used in upgrading biogas. Sodium hydroxide was used as absorbent for $\mathrm{CO}_{2}$ [3]. Many factors affected on the processes of biogas production were selected for laboratory tests such asBOD5, COD, Sulphide, Nitrate-N, Ammonia-N, and $\mathrm{pH}$, $\mathrm{NH}_{3}$, T.S, TVS and Ec.

There were two experiments took place for testing the biogas production; one experiment used Brewer's Yeast where the other not used the yeast. Biogas off gases emitted from the tannery waste compositing of lime, sulphide and deliming observed through ignition test. The stoichiometry equation used to quantify the quantity of methane produced was used a certain quantities of tannery waste water. The biogas absorber unit is used to stabilize the reactor and enhance the biogas quality.

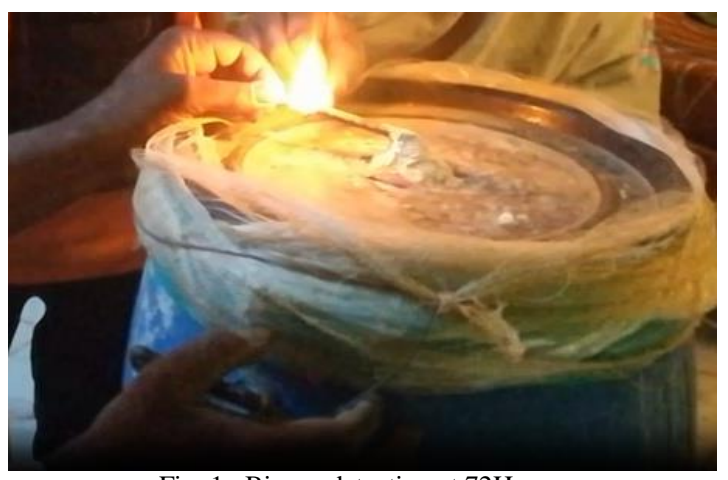

Fig. 1. Biogas detection at 72 Hours

$\mathrm{CH}_{4}$ generation rate per unit of COD removed [4]:

$1 \mathrm{Kg}$ COD $\Rightarrow 0.35 \mathrm{~m}^{3} \mathrm{CH}_{4}$

Effect of sulfate on methane production:

$$
\mathrm{SO}_{4}+\mathrm{C} \Rightarrow \mathrm{HS}+\mathrm{CO}_{2}
$$

\section{MATH}

The results and analysis of methane produced from liming and deliming solutions in anaerobic operation is shown in Table I and Fig. 2 
TABLE I: CHARACTERISTIC OF TANNERY WASTE WATER PRIOR TO ASBR

\begin{tabular}{ccc}
\multicolumn{3}{c}{ ARRANGEMENT OF CHANNELS } \\
\hline \hline $\mathrm{T}$ Test & Unit & Result \\
\hline $\mathrm{pH}$ & - & 12 \\
$\mathrm{Ec}$ & $\mu \mathrm{s} / \mathrm{cm}$ & 15520 \\
$\mathrm{BOD} 5$ & $\mathrm{mg} / \mathrm{L}$ & 7000 \\
$\mathrm{COD}$ & $\mathrm{mg} / \mathrm{L}$ & 14400 \\
$\mathrm{NH}_{3}$ & $\mathrm{mg} / \mathrm{L}$ & 462 \\
$\mathrm{~T}^{\mathrm{S}}$ & $\mathrm{mg} / \mathrm{L}$ & 28260 \\
$\mathrm{SO}_{4}$ & $\mathrm{mg} / \mathrm{L}$ & 14460 \\
$\mathrm{TVS}$ & $\mathrm{mg} / \mathrm{L}$ & 14100 \\
$\mathrm{~S}$ & $\mathrm{mg} / \mathrm{L}$ & 880 \\
Density & $\mathrm{Kg} / \mathrm{m} 3$ & 1.006 \\
\hline \hline
\end{tabular}

TABLE II: CONCENTRATION OF THE YEAST [5]

\begin{tabular}{ccc}
\hline \hline No & Characters & Value \\
\hline 1 & TS $(\mathrm{g} / 1)$ & $185 \pm 5$ \\
2 & VS $(\mathrm{g} / \mathrm{l})$ & $175 \pm 5$ \\
3 & COD $(\mathrm{g} / \mathrm{l})$ & $265 \pm 15$ \\
\hline \hline
\end{tabular}

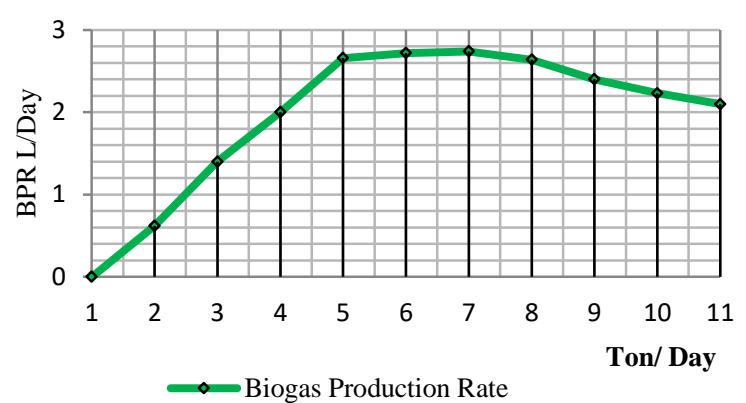

Fig. 2. Biogas Production Rate (BPR)

For biogas generation rate $(80 \%)$ :

Total COD removed $=0.288 \mathrm{~kg}$ COD $/$ day $\times 0.80=0.2304$

$\left(\mathrm{kg} / \mathrm{day}^{-1}\right)$

$0.2304 \mathrm{Kg}$ COD produces $=0.35 \times 0.2304$

$=0.08064 \mathrm{~m}^{3}$ of $\left(\mathrm{CH}_{4} /\right.$ day $)$ at STP.

At $35^{\circ} \mathrm{C}$, the $\mathrm{CH}_{4}$ gas generation $=0.08064(308 / 273)$ $=0.091 \mathrm{~m}^{3} \cdot$ day $^{-1}$.

Effect of sulfate on methane production:

Or. $\mathrm{M}+\mathrm{Nu}+\mathrm{SO}_{4} \Rightarrow \mathrm{H}_{2} \mathrm{~S}+\mathrm{H}_{2} \mathrm{O}+\mathrm{HCO}_{3}+\mathrm{N}$. mass

Total COD consumed in sulfate reduction $=(14.460) /(1.5)$ $=9.64\left(\mathrm{~g} . \mathrm{L}^{-1}\right)$.

In this problem, there is $14.460 \mathrm{~g} . \mathrm{L}^{\mathbf{- 1}}$. Presence of sulfate reduces methane yield by about $67 \%$. (9.64/14.400).

\section{DISCUSSION}

In sample for experiment one, biogas generation increased after the first day and subsequently reduced after reaching peak day (6th day). The rapid initial biogas production was due to readily biodegradable organic matter in all the substrates and due to the presence of high content of the methanogens.

Decrease in biogas production after reaching peak day may be due to decrease in amount of nutrient for microorganisms and due to decrease in microbial activities. In addition, toxic substances as sulfate, ammonia, Light metal, Heavy metal, Organic compound and Sulphide.
The $\mathrm{C} / \mathrm{N}$ ratio form tannery waste water in range (4.9 \pm 0.73 ) [1]. An optimum $\mathrm{C} / \mathrm{N}$ ratio is needed for anaerobic digestion process because an appropriate nutrient balance is required by anaerobic bacteria for their growth as well as for maintaining a stable environment.

For aerobic treatment $\mathrm{pH}$ range is between 6 and 8 but for anaerobic $\mathrm{pH}$ is a major key parameter, it ranges from 6.5 to 7.5. However, if this can be keep at 7.0 is the best. This is because in anaerobic treatment, growth of methanogenic bacteria should be in equilibrium with acidogenic bacteria. If $\mathrm{pH}$ decreases to acidic methogens cannot survive [6].

From the laboratory analysis the $\mathrm{pH}$ was 12 as in Table. I. The $\mathrm{pH} 12$ let the effluent becomes too alkaline, a great deal of $\mathrm{CO}_{2}$ will be produced, which will have the effect of making the mixture more acidic [7].

Level of Sulphide and sulfate in tannery waste water might be due the use of chemicals and to the sulfate and sulfide concentration in the tannery wastewater high. From literature, sulphide concentration between $100 \mathrm{ppm}$ and 150 ppm have inhibitory effects to methanation, Therefore the need to tackle this either prior to digestion or simultaneously is pertinent [6].

From laboratory analysis for this research $880 \mathrm{mg} . \mathrm{L}^{-1}$ of Sulphide and sulfate $14460 \mathrm{mg} . \mathrm{L}^{-1}$ obtained which led the biogas production not obtained without using Brewer's Yeast to decrease the effect of this indictor as in experiment two that no biogas produced due to not used of Brewer's Yeast.

In order to produce high amount of biogas there is a need for microorganism to access the substrate. Because the substrates act as a food for the microorganism, the lack of it will reduce biogas production. That is why increased amount of carbohydrate, lipid and protein were used in the digester. Controlling temperature and $\mathrm{pH}$ are very important for the growth of microorganism.

The amount of methane produced from analytical analysis around $30 \mathrm{~L}$; where the amount of biogas resulted from experiment one $(21.51 \mathrm{~L})$. The amount of methane is expected around $13 \mathrm{~L}$ according to general ratio of biogas analysis gas ratio's ( $60 \%$ methane and $40 \%$ carbon dioxide). The reasons for these different values related to other amount of inhibitors as sulfide, sulfate and ammonia which led to produce hydrogen supplied, ammonia and nitrogen.

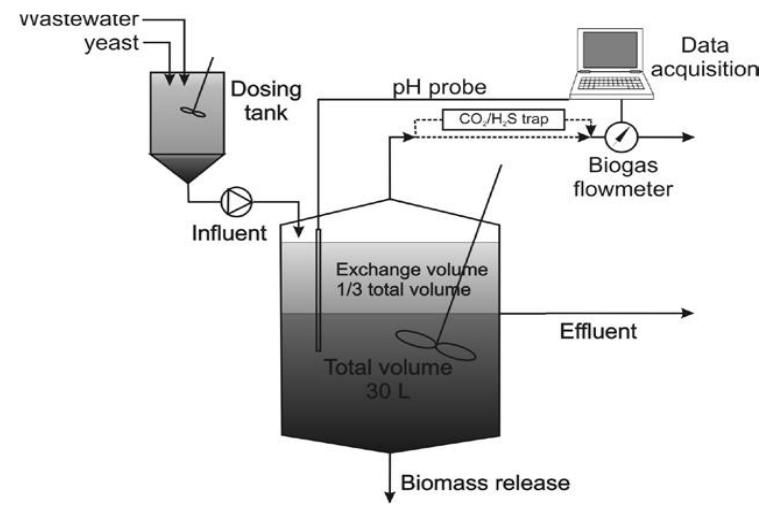

Fig. 3. Experimental anaerobic sequencing batch reactor (ASBR) setup [5]

Biogas is a promising alternative source of methane $\left(\mathrm{CH}_{4}\right)$ due to its availability and renewability. Unfortunately, high percentage of $\mathrm{CO}_{2}$ as well as traces of hydrogen sulfide 
and other material used in tanning process such sulfer. These compounds must be removed to obtain biogas of acceptable quality.

Use of sodium hydroxide to absorb carbon dioxide to improve the quality of biogas, this obtained as in Fig. 4. A syringe body fitted with flexible tube and dilutes sodium hydroxide $(\mathrm{NaOH})$ solution used to estimate carbon dioxide percentage for field purposes, as $\mathrm{NaOH}$ absorbs $\mathrm{CO}_{2}$ but not methane.

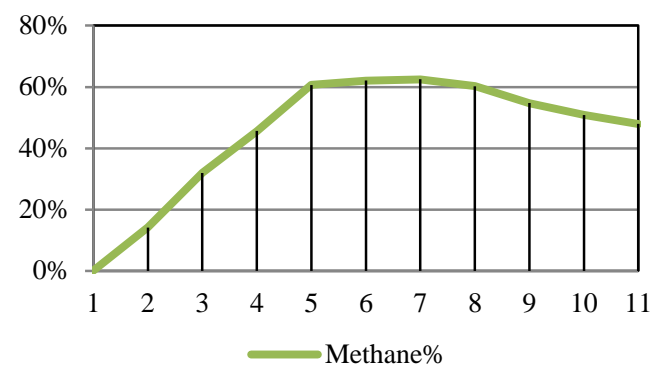

Fig. 4. Methane \% in the Biogas

\section{CONCLUSION}

The present practices of disposal of tannery waste water are not environmentally friendly and cause great concern for Khartoum City.

The waste water and solid waste can be utilized to generate biogas. The $\mathrm{C} / \mathrm{N}$ ratio of liming and deliming from tannery waste water is too low and alone is not suitable for biodegradation, but when mixed with Brewer Yeast the generation of biogas is very satisfactory.

Presence of sulfate reduces methane yield by about $67 \%$. The potential of biogas production from 20L tannery waste water with $100 \mathrm{~g}$ yeast about $0.0215 \mathrm{~m}^{3}$.
The biogas generated after three days. The generation of biogas from the tannery waste water is environmental friendly, hygienic and it will reduce pollution.

\section{ACKNOWLEDGMENT}

The author is thankful to Eng. Wadaah Ibrahim from ElAmatounj Tannery, Eng. Abd Elaziz Yousif for their help and support.

\section{REFERENCES}

[1] Bentley, RW. Global oil \& gas depletion, an overview.Energy Policy,(2002).

[2] Eye, J.D., and Lawrence, L. Treatment of waste from a sole leather tannery. J. Water Pollut. Control Fed. 43: 2291-2303 (1971).

[3] http://creativecommons.org/licenses/by-nc-nd/4.0. 29/9/2018 - 7:00 A.M.

[4] Anaerobic treatment and biogas, am 21.7.201411:4 Micros office $1.621 \mathrm{~KB}$ - Bio E 202 Iowa Univ. Sludge digester design -2.

[5] G.D.Zupancic, M.Panjicko and B. Zelic (2016) Biogas Production from Brewer's yeast Using an Anaerobic Sequencing Batch Reactor ISSN 1330-9862.

[6] Teodorit AL seadi, October 2008, Biogas Hand Book, Denmark, ISBN 978-87-992962-0-0.

[7] http://researchgate.net/biological water treatment. 29/9/2018 - 7:00 A.M

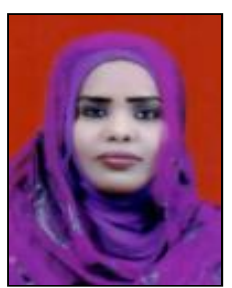

Ms. Aisha El-Awad M. Elamin. Sudan, 3/April/1979.

B.Sc in Chemical Engineering obtained from Red Sea University, Port Sudan, and Sudan.2004.

M.Sc in Chemical Engineering obtained from Alneelain University, Khartoum, and Sudan.2015.

Ph.D under progress, Karary university, Khartoum. Sudan. Since2016.

I am a researcher in Renewable and green Energy Sector as Private Work. I worked as a par timer at some engineering college in Khartoum. 